Halaman 31-40

\title{
Penerapan Problem Based Learning untuk Meningkatkan Kemampuan Berpikir Analitis Siswa Kelas X MIA 6 SMA MTA Surakarta Tahun Pelajaran 2013/2014 pada Materi Pencemaran Lingkungan
}

\author{
Implementing Problem Based Learning to Improve Analytical Thinking Students \\ in X MIA 6 Class of SMA MTA Surakarta Academic Year 2013/2014 \\ about Environmental Pollution Material
}

\author{
Ulya Granit Pramudita $^{\text {a }}$, Riezky Maya Probosari ${ }^{\text {b }}$, Sri Widoretno ${ }^{c}$ \\ ${ }^{a}$ Pendidikan Biologi FKIP UNS, Email: ulya.gp@gmail.com \\ ${ }^{\mathrm{b}}$ Pendidikan Biologi FKIP UNS, Email: riezkymp@gmail.com \\ ${ }^{c}$ Pendidikan Biologi FKIP UNS, Email: widoretnosri@gmail.com
}

Diterima 22 Agustus 2014, disetujui 23 September 2014

\begin{abstract}
This study was aimed to improve the students' analytical thinking ability of biology subject in X MIA 6 of SMA MTA Surakarta academic year 2013/2014 through the implementation of Problem Based Learning. This research is a class action research which consists of three cycles. Each cycle contains planning, implementing, observing and reflecting. The subject of this research is the students in X MIA 6 of SMA MTA Surakarta academic year 2013/2014. The data colecting techniques of this research are using observation, interview and documentation. The data validation of this research is using triangulation method. The data result of observation, interview and documentation are analyzed by using qualitative analysis which is done in three components, they are: data reduction, data presentation and drawing the conclusion or verification. The research procedure is using spiral method. The results show that students analytical thinking ability is increased in Pre-cycle, Cycle I, Cycle II and Cycle III. The average of students analytical thinking ability increase from $21,45 \%$ to $47,51 \%$. Identifying elements aspect increase from $22,42 \%$ to $53,33 \%$. Grouping and describing elements in categories aspect increase from 23, 64\% to 46, 67\%. Describing process aspect increase from 21, $21 \%$ to $46,06 \%$. Interpreting simple series of data aspect increase from $20 \%$ to $49,09 \%$. Expressing information in simple tables or graphs aspects increase from $20 \%$ to $42,42 \%$. This research's conclusion is the implementation of Problem Based Learning can improve analytical thinking ability of the student in X MIA 6 class at SMA SMA MTA Surakarta.
\end{abstract}

Key Words: problem based learning, analytical thinking

\section{Pendahuluan}

Belajar merupakan suatu proses pengalaman yang menimbulkan perubahan tingkah laku seseorang. Perubahan tingkah laku dilihat dari perubahan sifat fisik seseorang dan perubahan perilaku seperti kemampuan berpikir (Sagala, 2010). Kemampuan berpikir yang diperlukan untuk berkembang salah satunya adalah kemampuan berpikir analitis. Berpikir analitis merupakan kemampuan berpikir membagi masalah menjadi bagian yang penting dan tidak penting, menghubungkan setiap bagian secara sistematis dan mengenali konsekuensi di dalam proses pembelajaran (Art-in, 2012). Berpikir analitis di dalam proses pembelajaran dilakukan dengan cara menganalisis suatu permasalahan 
(Omika, 2013). Menganalisis adalah proses memecah materi menjadi bagianbagian penyusun dan menentukan hubungan antarbagian penyusun materi (Anderson \& Krathwohl, et al 2010).

Hasil observasi terhadap pembelajaran biologi yang dilakukan di kelas X MIA 6 SMA MTA Surakarta semester II Tahun Pelajaran 2013/2014 menunjukkan kemampuan siswa dalam mengidentifikasi bagian penting sebesar $22,42 \%$, mengelompokkan dan menjelaskan setiap bagian dalam kategori sebesar $23,64 \%$, menggambarkan proses yang berurutan dengan benar sebesar 21,21\%, menafsirkan data dengan sederhana sebesar $20 \%$ dan mengungkapkan informasi dalam tabel atau grafik sederhana sebesar 20\%. Rata-rata kemampuan berpikir analitis siswa kelas X MIA 6 sebesar 21,45\%.

Hasil observasi menunjukkan bahwa proses pembelajaran di kelas $\mathrm{X}$ MIA 6 kurang mengembangkan kemampuan berpikir analitis. Berpikir analitis di dalam proses pembelajaran dikembangkan dengan cara menganalisis suatu permasalahan (Omika, 2013). Proses pembelajaran yang banyak melibatkan kegiatan menganalisis salah satunya melalui model pembelajaran Problem Based Learning (Guedri, 2001). Model pembelajaran Problem Based Learning $(P B L)$ merupakan model pembelajaran yang menggunakan masalah sebagai langkah awal dalam mengintegrasikan pengetahuan baru dan melatih keterampilan menyelesaikan masalah sebagai tujuan utama proses pembelajaran (Sudarman, 2007). Proses pembelajaran PBL menurut Tan (2003) terdiri dari lima langkah kegiatan yaitu meeting the problem, problem analysis and learning issues, discovery and reporting, solution presentation and reflection dan integration, overview and evaluation.

Meeting the problem merupakan skenario awal pembelajaran berupa masalah tidak terstruktur yang bertindak sebagai stimulus untuk memperluas pengetahuan siswa. Masalah nyata yang tidak terstruktur menurut Chin (2013) membutuhkan pemikiran yang mendalam sehingga mampu mengakomodasi kemampuan analisis. Problem analysis and learning issues siswa mengaktifkan pengetahuan awal yang telah didapat sebelumnya, kegiatan meliputi identifikasi masalah, membuat rumusan masalah, analisis masalah dan mencari solusi untuk menyelesaikan permasalahan secara berkelompok melalui buku, jurnal, internet atau sumber lain yang relevan terhadap isu dan pertanyaan yang diajukan (Tan, 2013). Menganalisis masalah menurut Wichard (2012) dapat mengembangkan kemampuan berpikir 
analitis. Tahap Discovery and reporting merupakan tahap untuk siswa berkumpul dan berbagi informasi baru yang telah mereka temukan secara individu kemudian berdiskusi untuk mencari informasi lebih lanjut mengenai rumusan masalah yang telah dibuat. Guru membantu memastikan bahwa materi utama yang dipelajari tidak diabaikan. Berdiskusi menurut Martin (2005) merupakan bagian penting dalam berpikir analitis. Solution presentation and reflection merupakan tahapan melaporkan dan menyajikan solusi dari masingmasing kelompok dalam satu kelas. Fase keempat melibatkan proses tanya jawab. Kebiasaan bertanya dan menjawab menurut Maghfiroh (2011) mengembangkan kemampuan berpikir analitis. Tahap terakhir integration, overview and evaluation, integration yakni menggabungkan pengetahuan sebelum dan sesudah penyelesaian masalah, overview, menarik kesimpulan tentang tujuan pembelajaran yang telah dicapai dan evaluation adalah mengevaluasi pembelajaran yang telah dilakukan. Guru membantu siswa meringkas dan mengintegrasikan prinsip-prinsip utama dan konsep materi yang telah dipelajari. Pengambilan kesimpulan dalam pembelajaran menurut Rudy (2010) dapat mengembangkan kemampuan berpikir analitis.

\section{Metode Penelitian}

Penelitian adalah Penelitian Tindakan Kelas (PTK) yang bertujuan untuk meningkatkan kemampuan berpikir analitis melalui penerapan Problem Based Learning pada materi pencemaran lingkungan di kelas X MIA 6 SMA MTA Surakarta Tahun Pelajaran 2013/2014.

Prosedur penelitian mengikuti model yang dikembangkan oleh Kemmis dan Robin MC Taggart dalam Arikunto (2008) yang berupa model spiral yaitu dalam satu siklus terdiri dari tahap perencanaan, tindakan, observasi dan refleksi. Pelaksanaan tindakan siklus dilaksanakan setelah observasi prasiklus.

Penerapan tindakan berupa Problem Based Learning dilaksanakan dalam tiga siklus yaitu siklus I, siklus II, dan siklus III. Siklus I direncanakan dan dilaksanakan berdasarkan hasil analisis observasi pra-siklus, siklus II direncanakan dan dilaksanakan berdasarkan refleksi siklus I, dan siklus III direncanakan dan dilaksanakan berdasarkan refleksi siklus II sehingga penerapan Problem Based Learning meningkatkan kemampuan berpikir analitis. 


\section{Hasil dan Pembahasan}

Hasil penelitian menunjukkan perbandingan tingkat kemampuan berpikir analitis siswa rata-rata pada prasiklus, siklus I, siklus II dan Siklus III disajikan dalam Gambar 1.

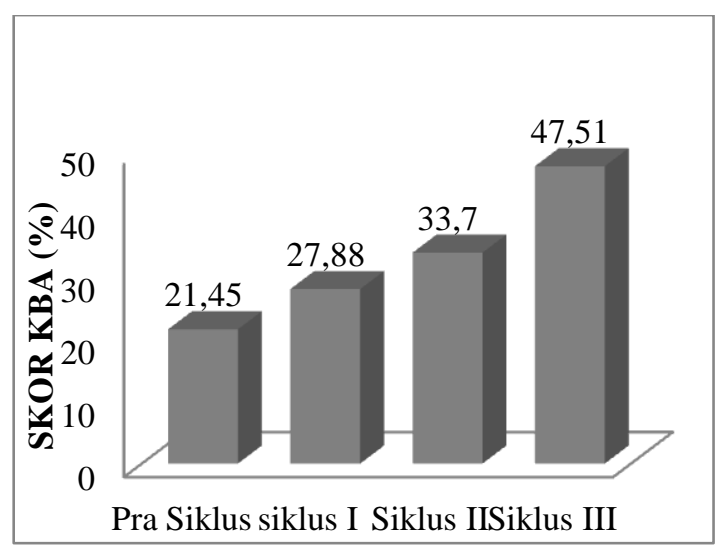

Gambar 1. Perbandingan hasil capaian kemampuan berpikir analitis rata-rata siswa pada pra siklus, siklus I, siklus II dan Siklus III

Gambar 1 menunjukkan bahwa skor kemampuan berpikir analitis siswa mengalami peningkatan dari prasiklus hingga siklus III. Peningkatan kemampuan berpikir analitis siswa dari prasiklus ke siklus I yaitu 6,43\%, peningkatan kemampuan berpikir analitis siswa dari siklus I ke siklus II sebesar $5,82 \%$, peningkatan kemampuan berpikir analitis siswa dari siklus I ke siklus II sebesar $13,81 \%$.

Kemampuan berpikir analitis siswa mengalami peningkatan selama tindakan penerapan Problem Based Learning menunjukkan bahwa Problem Based Learning memberi dampak positif bagi proses pembelajaran untuk meningkatkan kemampuan berpikir analitis.

Kemampuan berpikir analitis menurut Sanchez \& Ruis (2010) dilatihkan dan dikembangkan melalui metode yang melibatkan masalah dalam proses pembelajarannya dan model pembelajaran Problem Based Learning $(P B L)$ merupakan model pembelajaran yang menggunakan masalah sebagai langkah awal dalam mengintegrasikan pengetahuan baru dan melatih keterampilan menyelesaikan masalah sebagai tujuan utama proses pembelajaran (Sudarman, 2007). Husain \& Mokril (2012) menjelaskan bahwa pembelajaran berbasis masalah dapat meningkatkan kemampuan berpikir analitis dan berpikir kritis siswa. Penelitian yang dilakukan oleh Kim \& Lee (2014) menyatakan kegiatan menganalisis dan memecahkan masalah dapat diakomodasi dengan model pembelajaran $P B L$.

Penerapan model pembelajaran PBL menciptakan suasana belajar yang bermakna dan menjadikan siswa aktif dan mandiri untuk menemukan jawaban atas permasalahan yang telah dirumuskan oleh siswa sendiri. Guru sebagai fasilitator dalam proses pembelajaran memfasilitasi siswa untuk mencari dan 
merekonstruksi informasi yang telah didapat (Erdogan,2014).

Hasil wawancara kepada siswa menunjukkan bahwa model pembelajaran $P B L$ melatih siswa untuk memecahkan masalah sehingga membantu mereka dalam membiasakan diri untuk menganalisis suatu masalah dan memberikan kesempatan siswa untuk aktif mencari tahu konsep yang dipelajari dengan berdiskusi dan bertanya kepada teman atau guru dibandingkan dengan pembelajaran dengan metode ceramah seperti pada pembelajan prasiklus. Hasil penelitian Akinoglu (2007) menyatakan bahwa siswa lebih paham dengan konsep materi yang telah dipelajari melalui model pembelajaran PBL.

Kontribusi tiap siswa terhadap peningkatan kemampuan berpikir analitis dilihat Gambar 2.

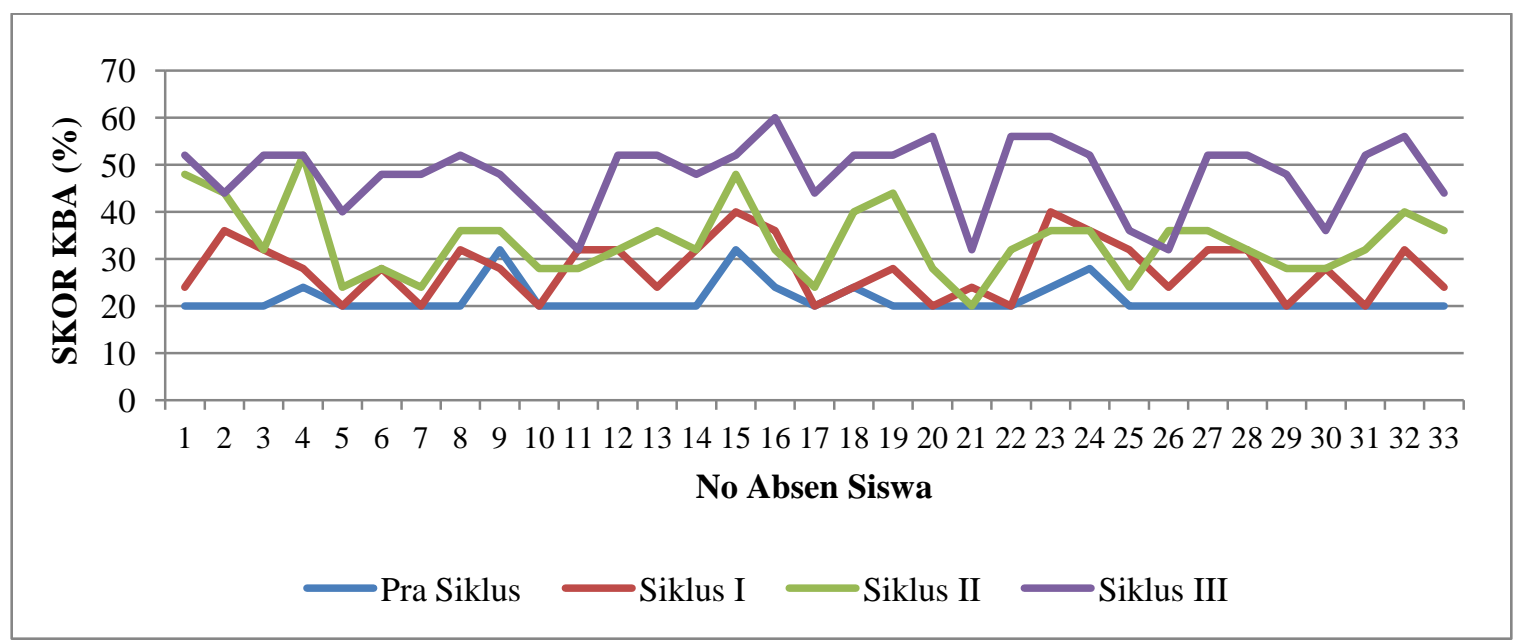

Gambar 2. Perbandingan Hasil Capaian Kemampuan Berpikir Analitis Setiap Siswa Pada Pra Siklus, Siklus I, siklus II dan Siklus III

Gambar 2 menunjukkan tiap siswa mempunyai skor kemampuan berpikir analitis yang berbeda tiap siklus tindakan. Siswa yang selalu mengalami peningkatan skor kemampuan berpikir analitis adalah siswa nomor 1 , $8,9,12,13,18,19,22,32$, dan 33. Siswa yang mengalami peningkatan dan penurunan skor kemampuan berpikir analitis adalah siswa nomor 2, 3, 4, 5, 6, 7, 10, 11, 14, 15, 16, 17, 20, 21, 23, 24, 25, 26, 27, 28, 29, 30, dan 31 .
Pelaksanaan model pembelajaran PBL terdiri dari 5 fase yaitu meeting the problem, problem analysis and learning issues, discovery and reporting, solution presentation and reflection dan integration, overview and evaluation.

Fase meeting the problem meningkatkan indikator kemampuan berpikir analitis yaitu mengidentifikasi bagian yang penting melalui kegiatan mengobservasi dan mengidentifikasi. Mengidentifikasi merupakan salah satu 
kegiatan yang melatihkan kemampuan berpikir analitis. Kemampuan mengidentifikasi menurut Tan (2003) diakomodasi oleh kegiatan skenario masalah nyata yang tidak terstruktur pada awal pembelajaran. Masalah nyata yang tidak terstruktur menurut Chin (2013) membutuhkan pemikiran yang mendalam sehingga mampu mengakomodasi kemampuan analisis.

Fase problem analysis and learning issues melatihkan indikator kemampuan berpikir analitis yaitu mengelompokkan bagian berdasarkan kategori, menggambarkan proses berurutan dengan benar dan mengidentifikasi bagian penting melalui kegiatan berdiskusi. Sanchez \& Ruis (2010) menyatakan bahwa kemampuan berpikir analitis dikembangkan melalui kegiatan identifikasi masalah dan analisis masalah pada saat berdiskusi. Yamin (2011) dan Sun (2007) menyebutkan bahwa fase awal model pembelajaran PBL merupakan fase siswa untuk menganalisis dan memahami masalah sehingga melatih siswa dalam mengembangkan kemampuan berpikir analitis.

Fase discovery and reporting melatihkan indikator kemampuan berpikir analitis yaitu mengungkapkan informasi dalam tabel atau grafik sederhana dan menafsirkan data dengan sederhana melalui kegiatan berdiskusi. Hasil penelitian yang mendukung dilakukan oleh Samah (2000) yang menyatakan bahwa membuat tabel atau grafik merupakan kemampuan dasar untuk membantu menarik kesimpulan dari analisis data yang telah dilakukan.

Fase Solution presentation and reflection melatihkan indikator kemampuan berpikir analitis yaitu mengelompokkan bagian berdasarkan kategori dan mengidentifikasi bagian penting melalui kegiatan bertanya dan menjawab. Kebiasaan bertanya dan menjawab menurut Maghfiroh (2011) dapat mengembangkan kemampuan berpikir analitis. Art-in (2012) menyatakan bahwa kegiatan presentasi dan diskusi dapat mengembangkan kemampuan berpikir analitis karena terjadi interaksi dan komunikasi antar siswa maupun antara siswa dengan guru sehinga melatih siswa untuk berpikir.

Tahap terakhir integration, overview and evaluation. Indikator kemampuan berpikir analitis yang dilatihkan pada fase kelima yaitu mengelompokkan bagian berdasarkan kategori pada saat menyimpulkan hasil pembelajaran. Rudy (2010) menyebutkan bahwa kegiatan yang mengakomodasi siswa untuk berpikir analitis adalah kegiatan menarik kesimpulan dalam pembelajaran. Schmidt 
menyatakan siswa mengembangkan kemampuan menganalisis melalui kegiatan refleksi pada akhir pembelajaran.
Perbandingan tingkat penguasaan setiap indikator kemampuan berpikir analitis siswa pada prasiklus, siklus I, siklus II dan Siklus III disajikan dalam Tabel 1.

Tabel 1. Skor Capaian Kemampuan Berpikir Analitis Siswa Setiap Indikator pada PraSiklus, Siklus I, Siklus II dan Siklus III

\begin{tabular}{|c|c|c|c|c|c|}
\hline \multirow[t]{2}{*}{ No } & \multirow[t]{2}{*}{ Indikator } & \multicolumn{4}{|c|}{ Capaian (\%) } \\
\hline & & Pra Siklus & Siklus I & Siklus II & Siklus III \\
\hline 1 & Mengidentifikasi bagian penting & 22,42 & 29,70 & 35,76 & 53,33 \\
\hline 2 & $\begin{array}{l}\text { Mengelompokan bagian dalam kategori } \\
\text { dengan benar }\end{array}$ & 23,64 & 30,91 & 36,36 & 46,67 \\
\hline 3 & $\begin{array}{l}\text { Menggambarkan proses yang berurutan } \\
\text { dengan benar }\end{array}$ & 21,21 & 30,30 & 33,33 & 46,06 \\
\hline 4 & Menafsirkan data dengan sederhana & 20 & 24,24 & 29,7 & 49,09 \\
\hline 5 & $\begin{array}{l}\text { Mengungkapkan informasi dalam tabel atau } \\
\text { grafik sederhana }\end{array}$ & 20 & 24,24 & 33,33 & 42,42 \\
\hline & Rata-rata & 21,45 & 27,88 & 33,70 & 47,51 \\
\hline
\end{tabular}

Tabel 1 menunjukkan skor capaian kemampuan berpikir analitis siswa setiap indikator pada prasiklus, siklus I, siklus II dan siklus III mengalami perbedaan.

Indikator 1 yaitu mengidentifikasi bagian penting mengalami peningkatan pada setiap siklus. Pada prasiklus memiliki nilai sebesar $22,42 \%$, kemudian siklus I meningkat menjadi 29,70\%, siklus II meningkat menjadi $33,70 \%$ dan siklus III meningkat menjadi 53,33\%. Kegiatan mengidentifikasi bagian menurut Robbins (2011) merupakan kemampuan siswa untuk membedakan bagian yang penting dan tidak penting dalam sebuah masalah atau kasus untuk diambil menjadi sebuah keputusan, sehingga melatih siswa dalam mengembangkan kemampuan berpikir analitis.
Peningkatan persentase skor kemampuan berpikir analitis pada indikator mengidentifikasi bagian penting merupakan indikator dengan peningkatan tertinggi yang disebabkan karena siswa sudah terbiasa untuk mengidentifikasi dan termasuk dalam kategori pemahaman yang lebih mudah dipelajari siswa. Maghfiroh (2010) menyebutkan kegiatan mengidentifikasi bagian merupakan kecakapan yang paling mudah dipelajari.

Indikator 2 yaitu mengelompokan bagian dalam kategori dengan benar mengalami peningkatan pada setiap siklus. Prasiklus memiliki nilai sebesar 23,64\%, kemudian siklus I meningkat menjadi 30,91\%, siklus II meningkat menjadi $36,36 \%$ dan siklus III meningkat menjadi 46,67\%. Behn (2005) menyebutkan bahwa mengelompokkan 
bagian merupakan kemampuan siswa untuk mengelompokkan dan menjelaskan setiap bagian dalam suatu kategori dan dapat menjadi petunjuk bagaiamana menyelesaikan masalah sehingga dapat mengembangkan kemampuan menganalisis. Peningkatan indikator mengelompokkan bagian diakomodasi model pembelajaran PBL dengan kegiatan diskusi (Adnyana, 2014).

Indikator 3 yaitu menggambarkan proses yang berurutan dengan benar mengalami peningkatan pada setiap siklus. Pada pra siklus memiliki nilai sebesar 21,21\%, kemudian Siklus I meningkat menjadi $30,30 \%$, Siklus II meningkat menjadi 33,33\% dan Siklus III meningkat menjadi 46,06\%. Robbins (2011) menyebutkan bahwa menggambarkan proses yang berurutan dengan benar adalah kemampuan siswa dalam menjelaskan bagaimana suatu proses terjadi dengan benar dan sistematis atau mengidentifikasi urutan waktu sehingga melatih siswa mengembangkan kemampuan menganalisis. Peningkatan indikator menggambarkan proses diakomodasi model pembelajaran PBL dalam kegiatan diskusi.

Indikator 4 yaitu menafsirkan data dengan sederhana mengalami peningkatan pada setiap siklus. Prasiklus memiliki nilai sebesar 20\%, kemudian siklus I meningkat menjadi $24,24 \%$, siklus II meningkat menjadi $29,7 \%$ dan siklus III meningkat menjadi 49,09\%. Hasil penelitian yang mendukung dilakukan oleh Davenport, et al (2001) menyatakan bahwa menafsirkan data merupakan kemampuan dasar yang dimiliki dalam mengembangkan kemampuan analitis untuk membuat pengetahuan baru serta menarik kesimpulan dari analisis data yang telah dilakukan. Peningkatan indikator menafsirkan data diakomodasi model pembelajaran PBL dengan kegiatan praktikum dan diskusi.

Indikator 5 yaitu mengungkapkan informasi dalam tabel atau grafik sederhana mengalami peningkatan pada setiap siklus. Prasiklus memiliki nilai sebesar 20\%, kemudian siklus I meningkat menjadi $24,24 \%$, siklus II meningkat menjadi 33,33\% dan siklus III meningkat menjadi $42,42 \%$. Peningkatan persentase skor kemampuan berpikir analitis pada indikator mengungkapkan informasi dalam tabel atau grafik sederhana merupakan indikator dengan peningkatan terendah dari prasiklus yang terjadi karena sebagian besar siswa masih mengalami kesulitan dalam membuat grafik dan belum terbiasa dalam mentabulasi data. Samah (2000) menyebutkan bahwa kemampuan membuat grafik dan kemampuan mengubah data menjadi suatu grafik disebabkan 
oleh faktor kurang terbiasanya siswa dalam membaca dan membuat grafik dan didukung penelitian yang dilakukan oleh Maghfiroh (2010) yang menyatakan ratarata siswa mengalami kesulitan belajar berkomunikasi yang diantaranya adalah kemampuan membuat diagram atau grafik. Kesulitan membuat diagram atau grafik disebakan karena ketika membuat sebuah diagram atau grafik, diperlukan kemampuan membangun model simbolik atau teoritis sehingga siswa dituntut memiliki daya abstraksi yang cukup baik.

Analisis data mengenai skor capaian kemampuan berpikir analitis siswa yang didukung oleh beberapa teori, mengindikasikan bahwa model pembelajaran $P B L$ memberikan pengaruh positif terhadap kemampuan berpikir analitis siswa.

\section{Simpulan}

Kesimpulan penelitian adalah penerapan Problem Based Learning meningkatkan kemampuan berpikir analitis pada materi pencemaran lingkungan di kelas X MIA 6 SMA MTA

Surakarta Tahun Pelajaran 2013/2014.

\section{Daftar Pustaka}

Adnyana, I. P., \& Suarni, N. K. (2014). pengaruh Penerapan Model Pembelajaran Kontekstual Berbasis Diskusi Kelompok Debat Terhadap Kemampuan Berpikir Analitis Mata Pelajaran PPKn Ditinjau Sikap SOsial
Siswa X MM SMK PGRI 2 Bandung. e-Journal Program Pascasarjana Universitas Ganesha, Vol.4

Akinoglu, O. (2007). The Effect of Problem Based Learning in Science Education on Students Academic Achievment, Attitude and Concept Learning. Eurasia Journal of Mathematics, Science \& Technology Education, 71-81

Anderson. L.W \& Krathwohl, D. (2010). A Taxonomy for Learning Teaching and Assesing. A Revision of Bloom's Taxonomy of Educational Objectives. New York: Addison Wesley Longman, Inc

Art-In, S. (2012). Development ofteacher's learning management emphazing on analytical thinking in Thailand. Social and behavioral Science, 3339-3344

Behn, R. D. (2005). Teaching Analytical Thinking. Policy Analysis, 663-674

Chin, C. (2013). Implementing Problem Based Learning in Biology. Nanyang Technological University, Singapore

Chin, C., \& Li-Gek, C. (2005). Problem Based Learning: Using Ill Structure Problems in Biology Project Work. Wiley InterScience

Dvenport, T., Jeanne, H., \& Long, D. (2001). Data To Knowledge to Result: Building An Analytic Capability. California Management Review, 1-12

Erdogan, T., \& Senemoglu, N. (2014). Problem Based Learning in Teacher Education: Its Promises and Chalenges. Social and Behavioral Sciences, 459-463

Guedri. (2001). Problem Based Learning: Bringing High Order Thinking to Buisness School. Neuman. 1-15

H.G. Schmidt. (1993). Foundations of Problem Based Learning: some explanatory notes. Med.Edu., 422-432

Husain, H., Mokri, S. S., Husain, A., Samad, S. A., \& M Ajid, R. A. (2012). The Level of Critical and Analytical Thinking Skills among Electrical and 
Electronical Engineering Students. Asian Social Science, Vol. 8

Kim, D. G., \& Lee, J. M. (2014). A Study on Inproving Information Processing Abilities Based on PBL. Turkish Online Journal of Distance Education-TOJDE

Lidinillah, D. (2013). Problem Based Learning. jurnal pendidikan inovatif

Maghfiroh dan Sugiyanto. (2010). Penerapan Pembelajaran Fisiska Bervisi Sets Untuk Meningkatkan Kemampuan Berpikir Analitis Peserta Didik Kelas X. Jurnal Pendidikan Fisika Indonesia, 6-12

Martin, K. D. (2005). Analytical Thinking in Asymetric Environment. Military Intelligence Professional Bulletin, 23-29

Martinis, Y. (2008). Paradigma Pendidikan Konstrutivistik. Jakarta: Gaung Persada Press

Robbins, J. (2011). Problem Solving, Reasoning and Analytical Thinking in a Classroom Environment. The Behaviour Analyst Today, Vol. 12

Sagala, S. (2010). Konsep dan Makna Pembelajaran. Bandung: Alfabeta

Samah. (2000). Kemampuan Siswa Memahami Grafik pada Konsep Biologi : Studi Deskriptif pada Siswa Kelas I MAN Kupang. Bandung: UPI

Sanchez, A., \& Ruiz, M. (2008). Competence Based Learning. Groningen: University De Deusto

Siva, M. V. (2013). Influence Of Intuition And Analytical Thinking On
Graphic Representation Of Problem Situations. Education and Technology research group-Paulista University (UNIP)

SMP, D. (2013). Panduan Penguatan Proses Pembelajaran Sekolah Menengah Pertama. Jakarta: Kemendikbud

Sudarman. (2007). Problem Based Learning: Suatu Model Pembelajaran untuk Meningkatkan Kemampuan Pemecahan Masalah. Jurnal Pendidikan Inovatif, vol. 2

Sugiyono. (2008). Metode Penelitian Kuantitatif, Kualitatif dan $R \& D$. Bandung: Alfabeta

Sun, Y. W. (2007). Problem Based Approach for Bioinformatics. International Journal of Instructional Media , 441-448

Tan, O. S. (2003). Problem Based Learning Innovation: Using Problems to Power Learning in the 21 Century. Singapore: Thomson

White, H. (2001). Problem Based Learning. Speaking of Teaching,1-12

Yamin, S. (2011). The Effect of Problem Based Learning on Critical Thinking Ability: A Theoritical and Empirical Review. International Review of Social Sciences and Humanities, 215221

Wichard, Z., and Otting, H. (2012). The Impact of Concept Mapping in the Process of Problem Based Learning. Interdisciplinary Journal of Problem Based Learning, 7 